\title{
Front Matter: Volume 9400
}

, "Front Matter: Volume 9400," Proc. SPIE 9400, Real-Time Image and Video Processing 2015, 940001 (13 March 2015); doi: 10.1117/12.2190578

SPIE Event: SPIE/IS\&T Electronic Imaging, 2015, San Francisco, California, United SPIE. States 


\title{
Real-Time Image and Video Processing 2015
}

\author{
Nasser Kehtarnavaz \\ Matthias F. Carlsohn \\ Editors
}

10 February 2015

San Francisco, California, United States

Sponsored by

IS\&T-The Society for Imaging Science and Technology

SPIE

Published by

SPIE 
The papers included in this volume were part of the technical conference cited on the cover and title page. Papers were selected and subject to review by the editors and conference program committee. Some conference presentations may not be available for publication. The papers published in these proceedings reflect the work and thoughts of the authors and are published herein as submitted. The publishers are not responsible for the validity of the information or for any outcomes resulting from reliance thereon.

Please use the following format to cite material from this book:

Author(s), "Title of Paper," in Real-Time Image and Video Processing 2015, edited by Nasser Kehtarnavaz, Matthias F. Carlsohn, Proceedings of SPIE-IS\&T Electronic Imaging, SPIE-IS\&T Vol. 9400, Article CID Number (2015)

ISSN: 0277-786X

ISBN: 9781628414905

\section{Copublished by}

\section{SPIE}

P.O. Box 10, Bellingham, Washington 98227-0010 USA

Telephone +1 3606763290 (Pacific Time) · Fax +1 3606471445

SPIE.org

and

IS\&T-The Society for Imaging Science and Technology

7003 Kilworth Lane, Springfield, Virginia, 22151 USA

Telephone +1 7036429090 (Eastern Time) · Fax +17036429094

imaging.org

Copyright @ 2015, Society of Photo-Optical Instrumentation Engineers and The Society for Imaging Science and Technology.

Copying of material in this book for internal or personal use, or for the internal or personal use of specific clients, beyond the fair use provisions granted by the U.S. Copyright Law is authorized by the publishers subject to payment of copying fees. The Transactional Reporting Service base fee for this volume is $\$ 18.00$ per article (or portion thereof), which should be paid directly to the Copyright Clearance Center (CCC), 222 Rosewood Drive, Danvers, MA 01923. Payment may also be made electronically through CCC Online at copyright.com. Other copying for republication, resale, advertising or promotion, or any form of systematic or multiple reproduction of any material in this book is prohibited except with permission in writing from the publisher. The CCC fee code is 0277-786X/15/\$18.00.

Printed in the United States of America.

Paper Numbering: Proceedings of SPIE follow an e-First publication model, with papers published first online and then in print. Papers are published as they are submitted and meet publication criteria. A unique citation identifier (CID) number is assigned to each article at the time of the first publication. Utilization of CIDs allows articles to be fully citable as soon as they are published online, and connects the same identifier to all online, print, and electronic versions of the publication. SPIE uses a six-digit CID article numbering system in which:

- The first four digits correspond to the SPIE volume number.

- The last two digits indicate publication order within the volume using a Base 36 numbering

system employing both numerals and letters. These two-number sets start with 00, 01, 02, 03, 04, 05, 06, 07, 08, 09, OA, OB ... 0Z, followed by 10-1Z, 20-2Z, etc.

The CID Number appears on each page of the manuscript. The complete citation is used on the first page, and an abbreviated version on subsequent pages. 


\title{
Contents
}

\author{
$\checkmark$ Authors \\ vii Conference Committee
}

\section{SESSION 1 REAL-TIME HARDWARE}

940002 Customized Nios II multi-cycle instructions to accelerate block-matching techniques [9400-1]

940003 Hardware design to accelerate PNG encoder for binary mask compression on FPGA [9400-2]

940004 Real-time algorithm enabling high dynamic range imaging and high frame rate exploitation for custom CMOS image sensor system implemented by FPGA with coprocessor [9400-3]

940005 Fast semivariogram computation using FPGA architectures [9400-4]

$9400062 \mathrm{D}$ to 3D conversion implemented in different hardware [9400-5]

940007 A real-time GPU implementation of the SIFT algorithm for large-scale video analysis tasks [9400-6]

\section{SESSION 2 REAL-TIME ALGORITHMS I}

940008 Real-time deblurring of handshake blurred images on smartphones [9400-7]

940009 Real-time object tracking for moving target auto-focus in digital camera [9400-8]

9400 OA Embedded wavelet-based face recognition under variable position [9400-9]

9400 OB Subjective evaluation of H.265/HEVC based dynamic adaptive video streaming over HTTP (HEVC-DASH) [9400-24]

\section{SESSION 3 REAL-TIME ALGORITHMS II}

9400 OD FIR filters for hardware-based real-time multi-band image blending [9400-11]

$9400 \mathrm{OE} \quad$ Iris unwrapping using the Bresenham circle algorithm for real-time iris recognition [9400-12] 
INTERACTIVE PAPER SESSION

$9400 \mathrm{OH} \quad$ Efficient fast thumbnail extraction algorithm for HEVC [9400-15]

9400 Ol Parallel hybrid algorithm for solution in electrical impedance equation [9400-17]

9400 oJ Fast-coding robust motion estimation model in a GPU [9400-18]

9400 OK Real-time single-exposure ROI-driven HDR adaptation based on focal-plane reconfiguration [9400-19]

$94000 \mathrm{M}$ Task-oriented quality assessment and adaptation in real-time mission critical video streaming applications [9400-21]

9400 ON A simulator tool set for evaluating HEVC/SHVC streaming [9400-22]

940000 Dynamic resource allocation engine for cloud-based real-time video transcoding in mobile cloud computing environments [9400-23]

9400 OP Impact of different cloud deployments on real-time video applications for mobile video cloud users [9400-25]

$94000 Q \quad$ Improving wavelet denoising based on an in-depth analysis of the camera color processing [9400-26]

9400 OR Impulsive noise suppression in color images based on the geodesic digital paths [9400-27]

9400 OS Optimal camera exposure for video surveillance systems by predictive control of shutter speed, aperture, and gain [9400-28]

9400 0T Real-time object recognition in multidimensional images based on joined extended structural tensor and higher-order tensor decomposition methods [9400-29]

9400 OV Near real-time operation of public image database for ground vehicle navigation [9400-31] 


\section{Authors}

Numbers in the index correspond to the last two digits of the six-digit citation identifier (CID) article numbering system used in Proceedings of SPIE. The first four digits reflect the volume number. Base 36 numbering is employed for the last two digits and indicates the order of articles within the volume. Numbers start with 00, 01, 02, 03, 04, 05, 06, 07, 08, 09, 0A, 0B...0Z, followed by 10-1Z, 20-2Z, etc.

Adedayo, Bada, 00

Akil, Mohamed, 03

Al Hadhrami, Tawfik, ON

Alcaraz Calero, Jose M., 00

Ali, E., OV

Botella, Guillermo, 02, 0J

Broussard, Randy P., OE

Bucio-Ramirez, Ariana, 0

Carmona-Galán, R., OK

Carothers, Matthew T., OE

Chang, Chih-Hsiang, 08

Chevobbe, Stéphane, OA

Cotret, Pascal, OA

Cyganek, Bogusław, OR, OT

Darouich, Mehdi, OA

de Sande, Francisco, OJ

del Río, R., OK

Dong, Xuanliang, 05

Fassold, Hannes, 07

Fernández-Berni, J., OK

García, Carlos, 02, 0J

González, Diego, 02

Gonzalez-Huitron, Victor, 06

Grecos, Christos, OB, OM, ON, 0O, OP

Guan, Haike, 09

Hernandez-Fragoso, Araceli, 06

Irondi, Iheanyi, $\mathrm{OB}$

Jacquot, Blake C., 04

Jeon, Gwanggil, $\mathrm{OH}$

Jeong, Jechang, $\mathrm{OH}$

Johnson-Williams, Nathan, 04

Kachouri, Rostom, 03

Kehtarnavaz, Nasser, 08, 0N

Khan, Kashif A., OP

Kleihorst, R., OK

Kozaitis, S. P., OV

Lagadapati, Yamuna, 05

Leblebici, Yusuf, OD

Lee, Wonjin, $\mathrm{OH}$

Liu, Tong, 09

Luo, Chunbo, OP

Menéndez, José Manuel, OS

Meyer Bäse, Anke, 02

Meyer Bäse, Uwe, 02

Ngo, Hau T., OE

Nightingale, James, $\mathrm{MM}, \mathrm{ON}$

Niinami, Norikatsu, 09

Philips, W., OK

Plichta, Mathias, $0 Q$
Ponomaryov, Volodymyr I., 06, 01

Popovic, Vladan, OD

Pourreza-Shahri, Reza, 08

Prieto-Matías, Manuel, 02, 0J

Rakvic, Ryan N., OE

Ramirez-Tachiquin, Marco, 0

Ramos-Diaz, Eduardo, 06, 0l

Robles-Gonzales, Marco, 01

Rodríguez-Vázquez, Á., OK

Rosner, Jakub, 07

Seybold, Tamara, $0 Q$

Shirvaikar, Mukul, 05

Smołka, Bogdan, OR, OT

Stechele, Walter, $\mathrm{OQ}$

Torres, Juan, OS

Wang, Qi, OB, OM, ON, OO, OP

Wang, Xinheng, $O P$ 


\section{Conference Committee}

Symposium Chair

Sheila S. Hemami, Northeastern University (United States)

Symposium Co-chair

Choon-Woo Kim, Inha University (Korea, Republic of)

Conference Chairs

Nasser Kehtarnavaz, The University of Texas at Dallas (United States)

Matthias F. Carlsohn, Computer Vision and Image Communication at Bremen (Germany)

Conference Program Committee

Mohamed Akil, École Supérieure d'Ingénieurs en Electronique et Electrotechnique (France)

Guillermo Botella, Universidad Computense de Madrid (Spain)

Roy Davies, University of London (United Kingdom)

Philip P. Dang, Intel Corporation (United States)

Barak Fishbain, Technion-Israel Institute of Technology (Israel)

M. Emre Celebi, Lovisiana State University Shreveport (United States)

Sergio R. Goma, Qualcomm Inc. (United States)

Christos Grecos, University of the West of Scotland (United Kingdom)

Mehrube Mehrübeoglu, Texas A\&M University Corpus Christi

(United States)

Antonio J. Plaza, Universidad de Extremadura (Spain)

Volodymyr Ponomaryov, Instituto Politécnico Nacional (Mexico)

Luis Salgado, Universidad Politécnica de Madrid (Spain)

Sergio Saponara, Università di Pisa (Italy)

Vinay Sharma, Apple Inc. (United States)

Mukul V. Shirvaikar, The University of Texas at Tyler (United States)

Athanassios N. Skodras, University of Patras (Greece)

Juan P. Wachs, Purdue University (United States) 
Session Chairs

1 Real-Time Hardware

Nasser Kehtarnavaz, The University of Texas at Dallas (United States)

2 Real-Time Algorithms I

Mukul V. Shirvaikar, The University of Texas at Tyler (United States)

3 Real-Time Algorithms II

Guillermo Botella, Universidad Computense de Madrid (Spain) 